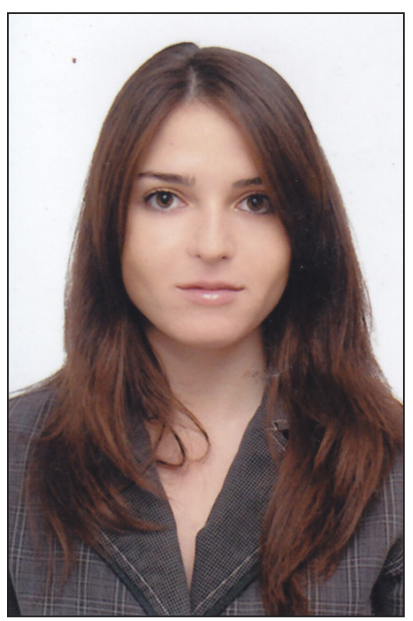

\author{
Сохікян Анна Суренівна, \\ здобувач кафедри кримінального права №1, \\ Начіональний юридичний університет \\ імені Ярослава Мудрого, \\ Україна, м. Харків \\ e-mail:anna.sohikyan.91@mail.ru
}

\title{
YАK 343.214
}

\section{ПОНЯТТЯ АЖЕРЕА КРИМІНААЬНОГО ПРАВА УКРАЇНИ}

Стаття присвячена дослідженню поняття джерел кримінального права. Наведений аналіз підходів до визначення поняття «джерело права». На підставі грунтовного дослідження чинного законодавства України виокремлено ознаки джерел кримінального права. За допомогою індуктивного методу дослідження надано визначення джерел кримінального права. Робиться висновок щодо необхідності визнання судового прецеденту джерелом кримінального права України.

Ключові слова: джерело права; джерела кримінального права; ознаки джерел кримінального права; судовий прецедент; Кримінальний кодекс України.

Сохикян $\boldsymbol{A}$. $\boldsymbol{C}$., соискатель кафедры уголовного права № 1, Национальный юридический университет имени Ярослава Мудрого, Украина, г. Харьков.

e-mail: anna.sohikyan.91@mail.ru

\section{Понятие источников уголовного права Украины}

Статья посвящена исследованию понятия источников уголовного права. Сделан анализ подходов к определению понятия источник права. На основании фундаментального исследования действующего законодательства Украины выделены признаки источников уголовного права. С помощью индуктивного метода исследования дано определение понятия источников уголовного права. Делается вывод о необходимости признания судебного прецедента источником уголовного права Украины.

Ключевые слова: источник права; источник уголовного права; признаки источников уголовного права; судебный прецедент; Уголовный кодекс Украины.

Постановка проблеми. Динамічний розвиток кримінального права, обумовлений необхідністю пошуку нових способів і засобів реагування на злочинність, відродив науковий інтерес до проблематики джерел даної галузі. Якщо протягом останніх десятиліть у вітчизняній науці панувала думка 
про те, що єдиним джерелом є виключно закон, то останнім часом вона все частіше піддається критиці. Зокрема, Б. Ш. Пошва вважає, що рішення, прийняті Верховним Судом України, мають набути статусу судового прецеденту [11, с. 25]. Ю. А. Пономаренко вказує, що рішення Конституційного Суду України щодо відповідності Конституції України (конституційності) положень кримінального закону, а також чинні міжнародні договори, згоду на обов’язковість яких надано Верховною Радою України, за умови, що останні безпосередньо визначають, які діяння є злочинами та якій відповідальності підлягають особи, що їх вчинили, мають бути визнані частиною кримінального законодавства [10, с. 43-44]. Деякі вчені розглядають правовий звичай як джерело кримінального права, при цьому вони не використовують по відношенню до нормативного звичаю термін «джерело кримінального права» [2; 4; 13].

Зауважимо, що при всьому різноманітті поглядів на природу джерел кримінального права вчені та практики ставлять під сумнів приналежність того чи іншого джерела права до розряду кримінально-правових. На наш погляд, вирішення зазначеного питання знаходиться в площині визначення самого поняття джерел кримінального права. Адже для встановлення юридичної природи будь-якого інституту потрібно чітко з’ясувати етимологічне і правове значення поняття (терміна). Погодимося з точкою зору М. I. Ковальова, який зауважує, що під визначенням чи дефініцією розуміється пояснення або сенс і значення будь-якого терміна чи обсягу, що його виражає цей термін через поняття [7, с. 14].

Очевидно, що поняття як таке не здатне цілком та повністю вирішити зазначену нами проблему. Більш того, визначення кола джерел кримінального права можливе лише тільки через виокремлення низки ознак із поняття. Адже поняття «джерело кримінального права» - це видове поняття по відношенню до джерел права в цілому. Як і будь-яке поняття в науці, воно має грунтуватися на загальнотеоретичних концепціях.

Ажтуальність теми. Суперечки щодо поняття «джерела права» періодично виникали в різні історичні епохи. Констатував зазначений факт i C. Ф. Кечек'ян, який писав, що зазначене поняття належить до числа найбільш нез’ясованих у теорії права, адже не тільки відсутнє загальноприйняте визначення цього поняття, а навіть дискусійним є сам сенс, який вкладають у цей концепт [8, с. 3].

На наш погляд, відповідь на питання стосовно кола джерел кримінального права може базуватися виключно на з’ясуванні поняття і ознак такого джерела. Інакше кажучи, тільки те явище, яке повністю буде відповідати усім науково обгрунтованим ознакам джерел кримінального права, й може бути віднесене до їх кола.

Аналіз останніх досліджень $\boldsymbol{i}$ публікацій. Дослідженню загальних і окремих питань джерел кримінального права присвятили свої праці 
П. П. Андрушко, М. І. Бажанов, І. В. Басков, С. В. Благов, Я. М. Брайнін, А. І. Бобилєв, В. М. Галкін, Л. Д. Гаухман, І. Я. Гонтар, А. Е. Жалінський, В. П. Коняхін, В. Г. Кучер, Д. В. Кухнюк, В. О. Навроцький, А. В. Наумов, К. В. Ображиєв, М. І. Панов, М. С. Палєєв, О. І. Рарог, А. С. Шляпочніков, М. Д. Шаргородський, Г. Ф. Шершеневич та інші. Їхніми зусиллями були виокремленні і описані окремі ознаки джерел кримінального права, вироблено основу для визначення дефініцій досліджуваного поняття тощо. Разом з тим багато положень розроблялося в період панування радянської системи права та відповідних їй наукових концепцій, окремі з яких сьогодні розглядаються суперечливо.

Mema cmammi - визначення поняття «джерела кримінального права». Застосовуючи індуктивний метод пізнання та доктринальний аналіз формальних і матеріальних джерел кримінального права, можна виокремити низку ознак, за допомогою яких ми дамо визначення поняттю «джерело кримінального права».

Історично термін «джерело права», за твердженням низки авторів, був вперше застосований Тітом Лівієм, який назвав закон XII таблиць «джерелом всього публічного і приватного права» [2, с. 51].

Визначення поняття джерел права досі залишає поле для дискусії. Так, Г. Ф. Шершеневич під джерелами права мав на увазі: а) сили, які створюють право (воля бога, народу, державна влада); б) матеріали, покладені в основу законодавства; в) історичні пам'ятки, «коли мало значення діюче право»; г) засоби пізнання чинного права [15, с. 368-369].

М. І. Панов зазначає, що термін «джерела права» застосовується в декількох значеннях: 1) в матеріальному - це економічні, політичні, духовно-культурні підстави, які породжують чи об'єктивно обумовлюють виникнення (створення) правових норм; 2) в ідеологічному - правова і політична свідомість суб'єктів правотворчості, що лежать у підгрунті формування правових норм; 3) в ретроспективному - історичні пам'ятки, пізнання яких надає можливість виявити зміст і сутність права минулого і його правових норм; 4) в формально-юридичному - спосіб і форма, за допомогою яких держава надає у правових актах певним узагальненим формам поведінки (діянь) загальнообов’язкової (юридичної) сили чи встановлює заборони щодо вчинення відповідних діянь. Далі автор доходить висновку, що в аспекті розглядуваних питань найбільш важливим є останнє значення. Під джерелом кримінального права в юридичному (формальному) його значенні М. І. Панов розуміє підстави визнання нормативно-правових актів, прийнятих у встановленій законом юридичній процедурі та формі, що містять кримінально-правові норми, які регулюють кримінально-правові відносини в Україні і на цій підставі відносяться до сфери (галузі) кримінального права [9, с. 35].

А. В. Міцкевич вказує, що юридичними джерелами або формами права «€ офіційні форми вираження і закріплення (зміни або скасування) право- 
вих норм, що діють в даній державі» [1, с. 230]. М. Й. Байтін, у свою чергу, під формою (джерелом) розуміє певні способи (прийоми, засоби) вираження державної волі суспільства [3, с. 67].

Під джерелом права насамперед слід розуміти ті факти, які безпосередньо обумовлюють відмінність правових соціальних норм від не правових і визначають, таким чином, специфіку права [1, с. 230]. Не можна не взяти до уваги визначення поняття С. Ф. Кечек’яном, який підкреслював, що джерело права в матеріальному сенсі - це причини, які обумовлюють зміст права, а джерело права в формальному сенсі - це причини юридичної обов'язковості норм [8, с. 3-5].

Аналізуючи такий підхід, ми доходимо логічного висновку, що джерела права в матеріальному та формальному сенсі існують як дві окремі субстанціï, причому одна субстанція (мається на увазі матеріальний сенс) обумовлює іншу (формальний сенс).

Вищезгадане розмежування понять джерел права притаманне і працям А. Е. Жалінського, який вважав, що вживання поняття джерела права в матеріальному сенсі як того, що породжує право, є непорозумінням. Відповідно до звичного позначення того, що породжує інше явище чи впливає на нього, краще казати про фактори, детермінанти, рушійні сили, умови, процеси становлення, походження тощо [6, с. 288-289].

Таким чином, А. Е. Жалінський дійшов висновку, що розглядати треба лише формальні джерела кримінального права. Допускаємо, що в даному контексті мова йде про способи закріплення та існування норм права.

Узагальнення існуючих точок зору на проблему джерел права привело вчених до думки, що під ними розуміються: 1) фактори, з яких випливає право, джерела пізнання права; 2) основа, з якої походить право; 3) те, що містить право, під яким розуміються норми, встановлені або закріплені на певному етапі панівним класом; 3) матеріальні умови життя суспільства; 4) форма або спосіб утворення, виникнення і вираження норми права, тобто те, з чого випливає обов’язкова сила останньої [6, с. 289].

Таким чином, джерела кримінального права залежно від різних критеріїв (наприклад, форми і змісту) можна розглядати з різних боків. Проте пропонуємо розглядати їх лише в формально-юридичному контексті.

Поділяючи думку А. Е. Жалінського, погодимося з його твердженням, що дефініції такого роду повинні бути адаптовані до правової матерії кримінального права, його завдань, принципів, змісту використовуваних правових засобів. Іншими словами, вони повинні відображати спеціальні ознаки джерел саме кримінального права, не ігноруючи при цьому ознаки, властиві всім джерелам права [6, с. 230].

Зазначимо, що одна кримінально-правова норма може бути висловлена в декількох правових актах. Проте постає запитання: якщо кримінально-правова норма не має єдиної форми вираження, то який зміст кримінально-правової норми можна вважати джерелом? 
Відомою є позиція вчених, відповідно до якої кримінально-правові норми ототожнюються тільки з нормами-правилами поведінки, що слугує підставою для невизнання юридичними джерелами кримінального права тих правових актів, які у своєму змісті мають установчий або додатковий характер.

Інша позиція вчених грунтується на твердженнях про те, що формальними джерелами кримінального права можуть вважатись не тільки ті правові акти, в яких зафіксовані первісні нормативи, а й правові акти, що містять вторинні, похідні правові норми. На думку цих вчених, постанови Пленуму Верховного Суду України не можна відносити до джерел кримінального права, оскільки їх зміст становлять не первісні норми, а лише конкретизація приписів первісних норм.

Аналізуючи вказані підходи, ми не погоджуємось із зазначеною вище позицією, адже для того, щоб визначити відповідний правовий акт, треба з'ясувати предмет правового регулювання фактичних юридичних норм, що в ньому містяться. Якщо правова норма регулює кримінально-правові відносини (зокрема, суспільні відносини, що виникають в результаті скоєння злочину між державою та особою, яка його вчинила, реалізацією громадянами права на заподіяння шкоди при наявності обставин, що виключають злочинність діяння, та ін.), то нормативно-правовий акт, в якому вона закріплена, слід вважати джерелом кримінального права.

Розвиваючи зазначену тезу, зауважимо, що деякі нормативно-правові акти мають комплексний характер або віднесені до інших галузей законодавства, проте останні містять окремі приписи, які за своєю суттю є кримінально-правовими, оскільки визначають кримінальну відповідальність за вчинення злочинів. Отже, такі нормативно-правові акти також слід розглядати як джерела кримінального права, проте тільки в тій частині, в якій вони містять зазначені кримінально-правові приписи. Такий підхід, зокрема, знайшов своє відображення в працях В. М. Самсонова [12, с. 78-79].

Норма кримінального права не може існувати сама по собі. Вона має бути закріплена у якій-небудь формі: письмовій або усній. Якщо ми говоримо про формальні джерела кримінального права, то кримінально-правові норми мають бути закріплені в письмовій формі.

Форма права є багатогранною, багаторівневою і багатозначною, не існуючою відокремлено. Вона не залежить від змісту явища. Формальність у кримінальному праві проявляється в закріпленні кримінально-правових норм у нормативно-правових актах. В аналізованому нами аспекті хотілося б приділити особливу увагу збігу джерела кримінального права і його форми, тобто формально-юридичному аспекту. Невипадково, всі зазначені вище джерела існують у правовій системі у вигляді нормативно-правових актів. Отже, формою джерел кримінального права має бути текстуально відображена норма, закріплена в нормативно-правовому акті. 
Окрім форми та змісту, важливе значення відіграє суб'єкт, який закріплює ту чи іншу норму як кримінально-правову. Так, юридична сила і соціальна значущість кожного джерела права залежить від того, яке місце в державних органах займає даний орган. Щодо джерел кримінального права, хотілося б відзначити, що тільки певні органи мають повноваження створювати відповідні нормативно-правові акти, вносити до них зміни і скасовувати останні. Так, Верховна Рада України здатна впливати на кримінальне законодавство, вносячи до нього зміни. Відтак, народні депутати України мають право подавати проекти законів щодо зміни кримінального законодавства.

Виходячи із цього, важливе місце в даному разі відіграє нормативність. Щодо ознаки нормативності слід погодитися з А. Е. Жалінським, який вважає, що зазначена вище ознака виявляється в можливості використання цього судження більш ніж в одному випадку, а також як певна ступінь пов'язаності адресата даної інформації характером ії впливу на поведінку .

Проте форми, змісту і суб'єкта прийняття недостатньо для того, щоб дійти висновку, які норми слід відносити до джерел кримінального права. Також аналізуючи ці категорії, ще складніше виокремити певні ознаки джерел кримінального права.

Зауважимо, що важливу роль відіграє процедура прийняття того чи іншого нормативно-правового акта, який містить кримінально-правові норми. Так, законодавством України чітко регламентований порядок, строки та інші процедурні питання, що стосуються прийняття та закріплення кримінально-правових норм.

У цьому контексті слід звернути увагу на загальнообов'язковість. Адже загальне визнання джерел кримінального права - це не тільки ті форми відношення держави і осіб, які проживають на даній території, до нормативно закріплених постулатів кримінального права, а й визнання і закріплення норм міжнародного кримінального права в національній системі. Яскравою ілюстрацією цього є рішення Європейського суду з прав людини, які не тільки обов'язкові для виконання Україною, але й визнаються частиною національного законодавства. Така ознака джерел кримінального права, як загальнообов'язковість, знаходить своє вираження в тому, що кримінально-правові норми, закріплені відповідним чином у нормативно-правових актах, носять обов'язковий характер для всіх осіб, які є суб'єктами кримінального права. Така позиція підтримується державою, а саме тим, що норми кримінального права $є$ імперативними. Недотримання кримінально-правових приписів тягне за собою відповідні санкції. Так, порушення суб'єктом кримінального права положень Кримінального кодексу неминуче призведе до застосування санкцій з боку держави.

Проте існування всіх цих структурних елементів (форма, зміст, суб'єкт та процедура прийняття), неможливе без системно-ієрархічних зв'язків. Так, одні окремо взяті акти і відповідно їх види мають більшу юридичну силу, 
ніж інші, і у разі виникнення між ними колізій перевага завжди виявляється на боці актів, які мають більшу юридичну силу. Так, рішення Конституційного Суду України володіють більшою силою, аніж навіть законодавчі приписи, про що свідчить рішення у справі про призначення судом більш м'якого покарання, згідно з яким в подальшому були внесені зміни до Кримінального кодексу України.

Такі ознаки джерел кримінального права, як системність і ієрархічність, ми пропонуємо розглядати в єдності, з використанням діалектичного методу дослідження, позаяк ці структурні елементи тісно пов’язані між собою.

Системність виявляється в наявності структурних елементів, системоутворюючих зв'язків, цілісності, автономії, відносної самостійності і динамічності. Ми дотримуємося тієї точки зору, що будь-яка система права сама по собі динамічна. Системність джерел кримінального права дає нам можливість не тільки виявити внутрішній механізм дії елементів, але й відображення цих самих елементів. Ієрархічність знаходить своє вираження в субординаційному порядку. Виходячи із загального уявлення про ієрархію, нормативно-правові акти нижчестоящих органів повинні перебувати в суворій відповідності 3 актами вищих органів, у той же час всі вони мають відповідати Конституції України, а їхні приписи не повинні суперечити один одному. Разом з тим зі зв'язками прямого підпорядкування між актами різної юридичної сили також встановлюються зв’язки координації, взаємодоповнення, деталізації нормативно-правових актів вищих органів влади. Так, зокрема, прецедент представлений такими видами, як рішення Конституційного Суду України, постанови Верховного Суду України та Європейського суду з прав людини. Системоутворюючі зв’язки випливають з ієрархії і значущості останніх. Цілісність полягає в тому, що при всій своїй автономії і відносній самостійності зазначені види судових рішень утворюють так звані прецеденти.

Взагалі динамічність характерна для будь-якого джерела кримінального права. Під впливом часу джерела права постійно змінюються. Якісь застарівають, і їх місце займають інші, або поряд з уже існуючими джерелами права з'являються нові, які, в свою чергу, дають інше тлумачення вже існуючим нормам кримінального законодавства. Причиною такої динаміки нерідко є суперечності в правозастосуванні. Так, інформаційні листи Вищого спеціалізованого суду з розгляду цивільних та кримінальних справ стали новелою в законодавстві України.

Висновки. Проаналізувавши різні підходи і точки зору, ми дійшли висновку, що до ознак джерел кримінального права варто віднести: нормативність; системність; ієрархічність; формальність, загальнообов'язковість.

Таким чином, під джерелами кримінального права слід розуміти явища, в яких містяться норми права, прийняті спеціальним суб'єктом, котрі мають конкретну загальноприйняту і загальнообов’язкову форму, визнану державою, і здатні регулювати кримінально-правові відносини. 
Підсумовуючи вищевикладене, зазначимо, що джерело права - це факти, які здатні ідентифікувати соціальні норми від неправових і, таким чином, визначити специфіку права. Джерела права мають різноманітний характер. Проте, щоб відрізняти кримінально-правові норми від інших норм, треба виокремити певну низку ознак, характерних саме для кримінально-правових приписів. На підставі цих ознак і визначається поняття «джерело кримінального права».

\section{Список літератури:}

1. Общая теория государства и права : академический курс / под ред. М. Н. Марченко. Москва : Зерцало, 2002. - Т. 2. - 816 с.

2. Александров Н. Г. Понятие источника права / Н. Г. Александров // Учёные труды. Москва : ВИЮН, 1946. - Вып. VIII. - С. 47-54.

3. Байтин М. И. Сущность права / М. И. Байтин. - Москва: Право и государство, 2005. $544 \mathrm{c}$.

4. Балобанова Д. О. Щодо співвідношення понять «динаміка» та «розвиток» [Електронний ресурс]/Д. О. Балобанова // Відповідальністьзакримінальні правопорушення у сучасному вимірі, присвяченої пам'яті українського криміналіста, професора Л. В. Багрій-Шахматова : матеріали інтернет-конференції (27 грудня 2013 року, м. Одеса). - Режим доступу : http:// 122 www.onua. edu.ua/index.php?option $=$ com_content $\& v i e w=$ article $\& i d=1885 \&$ Itemid $=645 \& l a n g=u k \&$ showall $=1$.

5. Бошно С. В. Соотношение понятий источник и форма права / С. В. Бошно // Юрист. 2001. - № 10. - С. 15-22.

6. Жалинский А. Э. Уголовное право в ожидании перемен: теоретико-инструментальный анализ / А. Э. Жалинский. - 2-е изд., перераб. и доп. - Москва : Проспект, 2015. 289 c.

7. Ковалев М. И. Соучастие в преступлении / М. И. Ковалев / Ек. : Б. и., 1999. - 190 с.

8. Кечекьян С. Ф. О понятии источника права / С. Ф. Кечекьян // Учёные записки МГУ. 1946. - Вып. 116. - Кн. 2. - С. 3-25.

9. Панов М. І. Вступ до навчального курсу «Кримінальне право України» : лекція / М. І. Панов. - Київ : Ін Юре, 2015. - 104 с.

10. Пономаренко Ю. А. Чинність і дія кримінального закону в часі : монографія / Ю. А. Пономаренко. - Київ : Атіка, 2005. - 288 с.

11. Пошва Б. М. Право на свободу та особисту недоторканність: прецедентна практика Європейського суду з прав людини і питання вдосконалення кримінального судочинства в Україні // Вісник Верховного Суду України. - 2011. - № 3. - С. 105-113.

12. Самсонов В. Н. Административное законодательство: понятие, содержание, реформа / В. Н. Самсонов. - Харьков : Основа, 1991. - 119 с.

13. Тарановский Ф. В. Учебник энциклопедии права / Ф. В. Тарановский. - Москва : Юрьев, 1917. - 272 с.

14. Туляков В. А. Многомерность уголовно-правового регулирования / В. А. Туляков // Проблеми законності : акад. зб. наук. праць / відп. ред. В. Я. Тацій. - Харьков : Нац. ун-т «ЮАУ», 2011. - Вип. 116. - С. 34-35.

15. Шершеневич Г. Ф. Общая теория права / Г. Ф. Шершеневич. - Москва : Изд-во бр. Башмаковых, 1911. - Вып. 2. - Т. 2. - 698 с.

Sokhikyan A. S., candidate for Ph. D. of the Department of Criminal Law № 1, Yaroslav Mudryi National Law University, Ukraine, Kharkiv.

e-mail: anna.sohikyan.91@mail.ru 


\section{The definition of the sources of the criminal law of Ukraine}

The article investigates the notion of the sources of criminal law. The approaches to definition of the source of law are analyzed. On the basis of fundamental research of the current legislation in Ukraine selected characteristics of the sources of criminal law. Using the inductive study method is the definition of sources of criminal law.

Obviously, the concept itself is not able entirely to solve the highlighted problem. Moreover, the identification of sources of criminal law is only possible through the selection of some traits from the concept. After all, the concept of «source of criminal law» is the species concept in relation to sources of law in General. As with any concept in science, it must be based on theoretical concepts.

From our point of view, the answer to the question about the range of sources of criminal law can be based exclusively on the clarification of the concepts and features of this source. In other words, only the phenomenon, which will fully meet all scientific indications of the sources of criminal law, and can only be attributed to them.

Given the above, the purpose of this article is the definition of «source of criminal law». Applying the inductive method of knowledge and doctrinal analysis of the formal and material sources of criminal law, we can distinguish a number of characteristics by which we define the concept of «source of criminal law».

A generalization of the existing points of view on the problem of the sources of law has led scientists to believe that it refers to: 1) factor, from which derives the right, the source of knowledge of law; 2) the basis from which comes the right; 3 ) that contains the right, meaning the standards set or fixed at a certain stage of a dominant class; the material conditions of society; 4) the form or method of formation, occurrence and expression of the rule of law, what should the mandatory power law.

Thus, the sources of criminal law, depending on various criteria (for example, form and content) can be viewed from different sides. However, we propose to consider the sources of criminal law only formal-legal.

The form of law is multi-faceted, multi-level and multi-valued, not existing in isolation. It is not based on the content of the phenomenon. Formality in criminal law is manifested in the enactment of criminal law norms in normative legal acts. The analyzed aspect I would like to pay special attention to the confluence of the sources of criminal law and its forms, that is, formal-legal aspect. Not coincidentally, all of the above sources exist in the legal system in the form of legal acts. Therefore, the shape of the sources of criminal law must be textually reflect the standards enshrined in legal act.

In addition to the form and content, plays an important entity that establishes a particular norm as criminal law. So, legal effectiveness and social significance of each source of law depends on what place in the state authorities took the body. Regarding the sources of criminal law, I would like to mention that only certain bodies have the authority to create relevant normative-legal acts, to amend and repeal the last. Thus, the Verkhovna Rada of Ukraine is able to influence the criminal legislation of Ukraine, with changes. Based on the foregoing, the people's deputies of Ukraine have the right to submit draft laws on amending the criminal law.

Key words: the source of the law; the source of the criminal law; the features of the sources of the criminal law; the precedent; the Criminal Code of Ukraine.

Надійшла до редколегіï 25.10.2015 p. 